\title{
ИССЛЕДОВАНИЕ НЕКОТОРЫХ СОВРЕМЕННЫХ ТЕРМОСТОИКИХ И ОГНЕСТОЙКИХ ХИМИЧЕСКИХ ВОЛОКОН МЕТОДОМ ИК-СПЕКТРОСКОПИИ
}

Термостойкие волокна - это материалы, отвечающие требованиям современной техники. Они, обладая большой механической прочностью, стабильны к воздействию не только высоких температур - до $2000^{\circ} \mathrm{C}$, но и различных видов излучения (космических, рентгеновских лучей и т. д.). Сверхустойчивые свойства мономера или полимера достигаются модификацией с термостабилизирующими добавками металлов, неметаллов или окисей. Широкие перспективы в этом смысле имеют стекловолокна, углеродные и графитированные волокна $[1,2]$. Модифицированием молекулярной структуры полиамидов (например, введением добавок, содержащих гидроксильную группу) получают волокна т. н. «второго поколения» с улучшенными свойствами (антистатические и др.) $\left[{ }^{3}\right]$.

Исходным сырьем для углеродных волокон служат лигнин, целлюлоза или вискозное волокно, а также бутадиен, полиакрилонитрил, различные смолы и нефтяные фракции. Основой получения термостойких волокнистых материалов являются как органические, так и неорганические добавки. Огнезащитные добавки - это те соединения, которые, меняя состав пиролизных газов волокна, или образуют негорящие продукты пиролиза, или способствуют покрытию поверхности волокна слоем огнезащитного углерода. Огнезащитными свойствами обладают многие неорганические и содержащие гетероатомы органические соединения [ $\left.{ }^{4}\right]$. Широко применяется комбинирование неорганических веществ (трехокись сурьмы, ортофосфорнокислый аммоний, борная кислота, бораты натрия и цинка) с органическими соединениями (галогенпроизводные, дицианамид и т. д.). Галогенпроизводные, употребимые как огнезащитные агенты, - это добавки или сам полимеризирующийся мономер. Добавками-пластификаторами служат хлорпарафины, хлорированные ди- и полифенилы. Пластификаторами-антипиренами, вводимыми в полиэфирные волокна, являются ангидрид тетрахлор- и тетрабромфталевой кислоты.

Химический состав многих огнестойких волокон еще мало изучен, и ИК-анализ позволяет несколько восполнить этот пробел.

\section{Обсуждение результатов}

В настоящей работе по ИК-спектрам (рис. 1-4) рассматривается состав следующих образцов новейших огнестойких волокон как неорганического, так и органического происхождения: 


\section{Волокно}

Авкерам $C S$

Авкерам RS

Углеродное

Углеродное

Рефрасил

Каовул

Модакрил

Орлон 775 , самозатухающий

Верел $F$

Верел $A$

Кантреце

Поливинилхлорид огнестойкий

Кинол

Поликарбонат

Номекс 450

Кевлар

Киана
Его вид

Керамическое

Керамическое

Углеродное

Графитированное

Стеклянное

Алюмосиликатное

Модифицированное полиакрилонитрильное

Полиакрилонитрильное

Сополимеризат из акрилонитрила и метакриламида

Сополимеризат из акрилонитрила и метакриламида

Сополимеризат из поливинилалкоголя и поливинилхлорида

Поливинилхлоридное

Новолаковое

Поликарбонатное

Ароматическое, полиамидное

Ароматическое, полиамидное

Алициклическое, полиамидное

Спектры снимались по использованной нами ранее методике, и спектры модифицированных полимеров сравнивались со спектрами обычных аналогов без огнестойких добавок [5].

Неорганические керамические волокна представлены двумя образцами - авкерамом $C S$ и $R S$ (рис. $1,1,2)$. Первый из них - углеродное волокно, содержащее двуокись кремния. Процесс окисления при получении этого волокна проводился до этапа, когда остаток органического вещества оказывался ничтожным, что видно по слабым полосам при 2865 и $2930 \mathrm{~cm}^{-1}$. Неорганическая часть характеризуется интенсивными полосами $\mathrm{Si}-\mathrm{O}$ - $\mathrm{Si} 1020$ - 1100 и $465 \mathrm{~cm}^{-1}$. Исходным сырьем для этого волокна служило целлюлозное волокно с добавкой силиката натрия [']. Авкерам $R S$, в котором содержится органическая двойная связь $\mathrm{C}=\mathrm{C}$ (1640 и $\left.3070 \mathrm{~cm}^{-1}\right)$, метиленовые и метильные группы $\left(1380\right.$ и $\left.1450 \mathrm{~cm}^{-1}\right)$, не гидрируется с $\mathrm{SiO}_{2}$ углеродного волокна [6, i]. Широкая интенсивная полоса 900 - 1250 с. ${ }^{-1}$ указывает, что, кроме $\mathrm{SiO}_{2}$, в волокне присутствуют и другие неорганические вещества. Это воспламеняющееся волокно сложного состава.

Углеродные волокна (рис. 1, 3 и 4), конечные продукты карбонизации и графитирования, представляют собой почти чистый углерод.

Стекловолокно (рефрасил; рис. 1,5 ) характеризуется широкой поло-

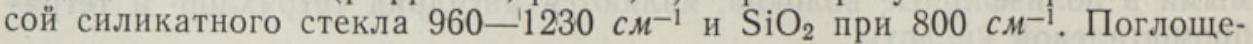
ние алюмосиликатного волокна (рис. 1, 6) - 430-470 и 1630 c. $^{-1}$.

Нз волокон органического происхождения ранее нами было интерпретировано полиакрилонитрильное [7]. Здесь рассматриваются лишь некоторые образцы теплостойких типов. Модакрил - сополимеризат ( $80 \%$ полиакрилонитрила с $20 \%$ винилхлорида и винилиденхлорида) дает валентные колебания связи $\mathrm{CH}-\mathrm{Cl}$ при 650 и $730 \mathrm{~cm}^{-1}$.

Волокно верел (рис. 2, 3 и 4) - сополимеризат полиакрилонитрила c N-метакриламидом; характеризуется амидными полосами 1650 и $1535 \mathrm{~cm}^{-1}$. Термостойкими агентами для этого волокна, как и для орло- 


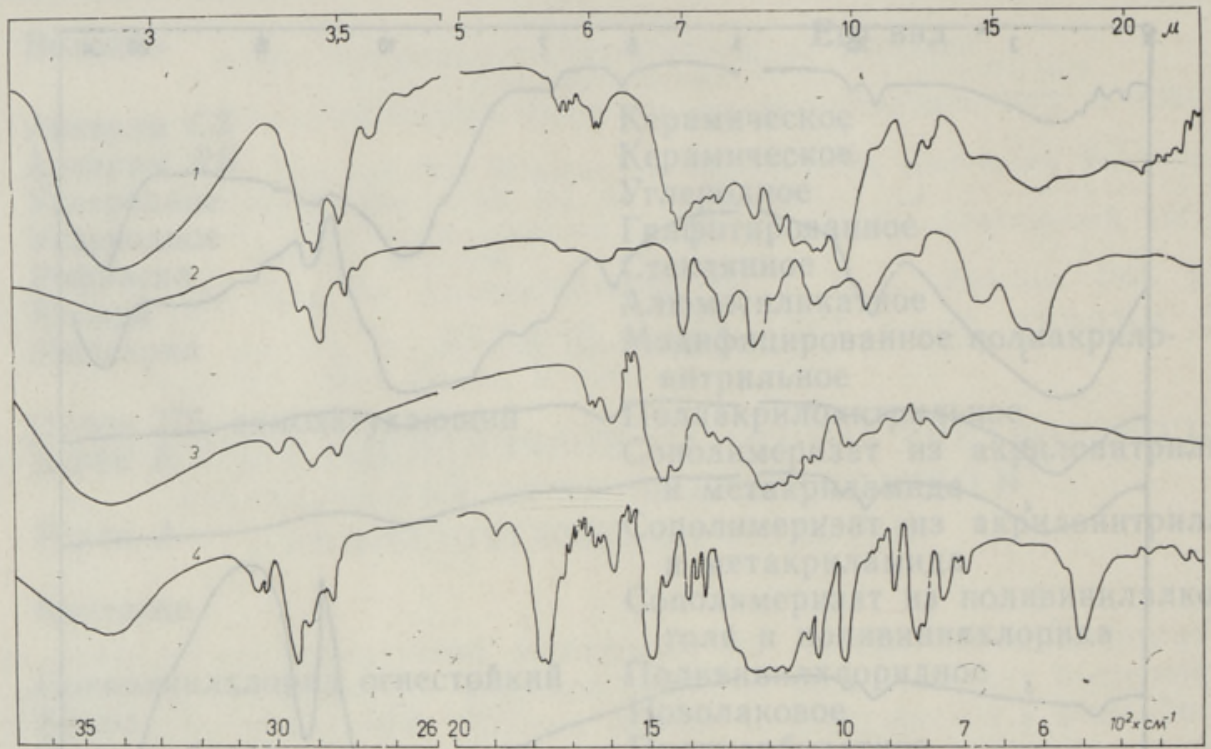

Рис. 3. ИК-спектры разных волокон: 1 - сополимеризат поливинилового спирта и поливинилхлорида, 2 - поливинилхлорид огнестойкий, 3 - кинол огнестойкий, $4-$ поликарбонат.

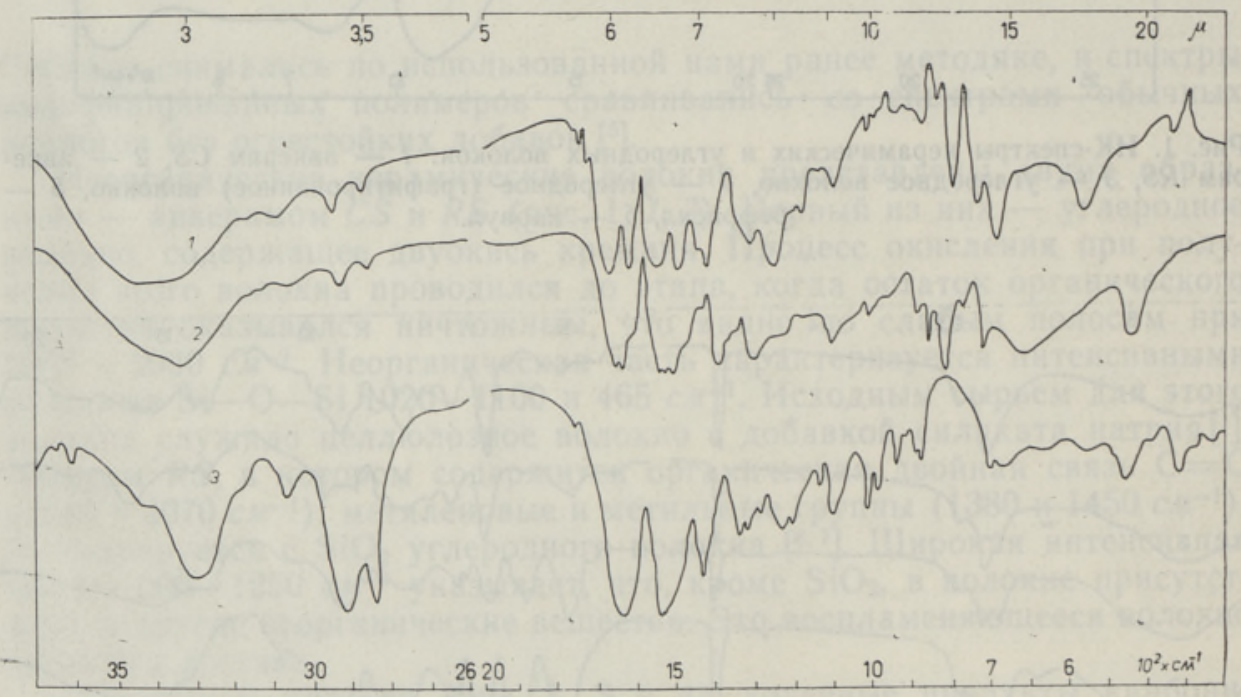

Рис. 4. ИК-спектры ароматических полиамидов: 1 - номекс 450, 2 - кевлар, 3 - киана.

Невоспламеняющийся японский поливинилхлорид с исправленными свойствами характеризуется полосами хлора $\left(615,635,685\right.$ см $\left.{ }^{-1}\right)$, производные которого и придают ему термостойкий характер. В привитых сополимеризатах роль хлора менее заметна (рис. 3, 1). Наблюдаются как деформационные, так и валентные колебания ОН-группы главного компонента 1025, 1070, 1100 и $3440 \mathrm{~cm}^{-1}$ (сополимер поливинилового спирта с поливинилхлоридом). В волокне присутствуют в небольшом количестве двойные связи $\mathrm{C}=\mathrm{C}\left(1645 \mathrm{~cm}^{-1}\right)$ и карбонильные группы $\left(1732 \mathrm{CM}^{-1}\right)$. 
ИК-спектр поликарбонатного волокна полностью совпадает с приведенным в литературе спектром поликарбоната, синтезированного на базе дифенила $A[4,8]$. Это ароматический полиэфир, содержащий изопропильную группу (дублет 1370, 1390 см.-1). Поликарбонат является термостойким, но воспламеняющимся материалом.

Из спектров полиамидных волокон представлены спектры номекса, кевлара и кианы (рис. 4), находящих широкое бытовое и техническое применение [9]. Хотя эти ароматические полиамиды и имеют общие для этой группы полосы, однако их спектры резко отличаются друг от друга в области $800-1000$ и $1300-1400 \mathrm{~cm}^{-1}$. По-видимому, добавки для придания волокну желаемых свойств разные. Киана и кевлар, наряду с амидными полосами, содержат и полосы, характеризующие амин: слабые 2340 и $2370 \mathrm{~cm}^{-1}$ полосы указывают на ненасыщенную аминную группу, которая доказывается и полосами 1310,1340 и $1360 \mathrm{~cm}^{-1}$. Возможно, амин и придает волокну огнестойкость.

Стабилизатором для кианы и номекса служит, очевидно, сложный эфир фосфорной кислоты (характерные полосы $1240-1255$ и 1120 $1130\left(\mathrm{CM}^{-1}\right)$.

Кевлар имеет в области $800-900$ см ${ }^{-1}$ полосы, очевидно, замещенных бензолов $\left(825,865\right.$ и $\left.895 \mathrm{~cm}^{-1}\right)$, являющихся огнестойким агентом. Из вышеназванных трех волокон наиболее ароматичен номекс, что видно по наиболее четким полосам ароматического кольца 1610, $1485 \mathrm{~cm}^{-1}$. Номекс имеет полосы $\mathrm{C}-\mathrm{Cl}$ при 675 и $780 \mathrm{~cm}^{-1}$ для полизамещенных хлорорганических соединений [5].

Как уже было упомянуто, ароматические огнестойкие полиамиды применяются все шире. Из номекса изготавливается защитная одежда для работников авиации и верхний слой одежды американских космонавтов, а также ковры в школах, гостиницах и в концертных залах [ $\left.{ }^{3}\right]$. Кевлар, который производится в США с 1971 г. фирмой «Ду Понт», отличается высокой прочностью и стойкостью. Из кианы изготавливают шелковистые текстильные изделия.

\section{Выводы}

1. Метод ИК-спектроскопии позволяет очень легко отличать термо- и огнестойкие неорганические химические волокна от термо- и огнестойких органических химических волокон.

2. По ИК-спектрам термо- и огнестойких органических полимеров, кроме специфичных для полимера полос поглощения, можно определить структурные элементы веществ (антипиренов и др.), которые придают полимерам термо- и огнестойкие свойства.

\section{ЛИТЕ РА Т У РА}

1. Конкин А. А. Углеродные и другие жаростойкие волокнистые материалы. М., 1974.

2. Dawczynski, H. Temperaturbeständige Faserstoffe aus anorganischen Polymeren. Berlin, 1974.

3. Koch, P. A. Polyester. - Chemiefasern Gesamte Textil-Industrie, 1975, Nov. S. $1-8$.

4. Hummel/Scholl, Atlas der Kunststoff-Analyse. Bd. I, II. München, 1968-1973.

5. К а зи цын а Л. А., К уплетска я Н. Б. Применение УФ-, ИК- и ЯМР-спектроскопии в органической химии. М., 1971.

6. Н а к а н и и К. ИК-спектры и строение органических соединений. М., 1965.

7. Kirret, O., Küllik, E., Lahe, L. Ober die Identifizierung von Bikompo. 
nentfasern mittels der Infrarot-Spektroskopie und Pyrolyse-Gaschromatographie. - ENSV TA Toim. Keemia * Geoloogia, 1974, Bd. 23, N 3, S. 187-192. 8. С м и рнов а О. В., Е рофе ев а С. Б. Поликарбонаты. М., 1975.

9. Термо-, жаростойкие и негорючие волокна. Под редакцией А. А. Конкина. М., 1978.
Институт химии
Академии наук Эстонской ССР
Поступила в редакцию 5/IX 1979

O. KIRRET, Lilja LAHE, Maret KRULL

\section{MONEDE KUUMUS- JA TULEKINDLATE KEEMILISTE KIUDAINETE UURIMISEST INFRAPUNASE SPEKTROSKOOPIA ABIL}

Infrapunaste spektrite alusel on vördlemisi lihtne eristada anorgaanilisi ja orgaanilisi kuumus- ja tulekindlaid keemilisi kiudaineid. Artiklis käsitletud anorgaaniliste kiudainete (keraamilised, alumosilikaatsed, klaas- ja süsinikkiud) infrapunastes spektrites esineb suhteliselt vähe absorptsiooniribasid. Seevastu on orgaaniliste polümeerkiudude infrapunastes spektrites polümeeri struktuurielementidele omaseid absorptsiooniribasid rohkesti, peale selle esineb neis veel lisandainete (polümeeridele kuumus- ja tulekindlust andvate ainete) absorptsiooniribasid.

O. KIRRET, Lilja LAHE, Maret KRULL

\section{ON THE STUDY OF SOME MODERN HEAT- AND FLAME-PROOF CHEMICAL FIBRES BY INFRARED SPECTROSCOPIC METHOD}

In this article the results are presented of the study of heat- and flame-proof inorganic and organic chemical fibres by infrared spectroscopy. By infrared spectra, inorganic and organic heat- and flame-proof chemical fibres are quite easily distinguishable from each other. Inirared spectra of inorganic chemical fibres investigated in this work (ceramic, alumosilica, glass and carbon fibres) contain relativity few absorption bands.

On the other hand, the infrared spectra of organic polymer fibres contain, besides the absorption bands characteristic of polymer structural elements, also those of additional compounds (which give polymers heat- and flame-proof properties). 